\title{
TRAINING OF ENGINEER-TECHNICAL SPECIALISTS: GENDER STEREOTYPES IN THE PROFESSIONAL SPHERE
}

\author{
MYKHAILO PALAHNIUK
}

\begin{abstract}
The article highlights the urgency of the problem of training engineering and technical professionals, taking into account the development of technology and social challenges of the market economy. Emphasis is placed on the need to ensure gender equality in the choice of engineering professions, equal opportunities for men and women. The essence of the concepts: "gender", "gender pedagogy", "gender culture", "gender socialization", "gender stereotypes", "gender competence", "gender education", "gender inequality", "gender roles" and others are substantiated. It is determined that gender studies are of great interest for pedagogical and psychological science, as they relate to the gender-role socialization of a person, his/her personal and professional development. The results of an empirical study on gender stereotypes in occupational choice among students of Ivano-Frankivsk National Technical University of Oil and Gas are presented (110 people took part in the survey). It has been revealed that gender is not the prerogative of many young people in engineering profession choice, however, such stereotypes still exist in the society. It was proven that for future professionals in this field, gender discrimination took place in their lives ( $28.4 \%$ of respondents) and it is mostly female who acquire technical professions. One third of students (32\%) admitted that they had faced cases of unequal wages to men and women. It has been proven that negative gender stereotypes are more subjective than objective, which gives hope for a fundamental possibility of overcoming them in the training of specialists at the Technical University.
\end{abstract}

Keywords: gender pedagogy, gender culture, gender stereotypes, vocational training, engineering education, gender equality, gender discrimination.

\section{INTRODUCTION}

In modern conditions, the problem of training engineering and technical specialists, competitive in the labor market, capable of professional self-improvement and use of innovations in professional work is especially relevant. The problem of improving the quality of professional training of engineers, in particular in Ukraine, is due to the "need to provide industrial enterprises of the national economy with qualified, proactive staff on the basis of thorough training, who quickly adapt to changing market conditions, creatively show active independence in solving professional problems of organizing resource-saving technologies for the production of competitive goods and engineering services" [9]. At the same time, in this area we still have the dominance of gender stereotypes regarding occupational choice, the priority of some of them only for men or women, gender inequality in wages, etc. It is no coincidence that the Association Agreement with the EU refers, inter alia, to "ensuring gender equality and equal opportunities for men and women in employment, education and training, economic and 
social activities, as well as in the decision-making process" [1]. There are social stereotypes in occupational choosing, among which gender stereotypes are of the most important. Thus, society is dominated by a typically masculine image of the profession, associated with professional competence, rational thinking and active life position, as well as typically female - with social and communication skills, warmth and emotional support. Therefore, despite the declaration of "equal opportunities" for men and women in mastering a profession, stereotypes in Ukraine about "male" or "female" specialties still prevail among a large number of citizens [18, p. 33].

The aim of the article is to substantiate theoretical aspects of professional training in engineering and technical education, to present the results of an empirical study of gender stereotypes in the occupational choice among students of technical universities.

\section{RESULTS AND DISCUSSION}

For theoretical justification study will use basic principles to the analysis of key concepts.

Gender is a socio-cultural, symbolic construction of gender that is designed to define a specific associative relationship, ensure full communication, and maintain social order. In other words, gender is a system of values, norms and characteristics of male and female behavior, lifestyle and way of thinking, roles and relationships of women and men, acquired by them as individuals in the process of socialization, modeled by society and supported by social institutions, which is primarily determined by social, political, economic and cultural contexts of life and captures the idea of women and men depending on their gender" [15].

"Gender is a social feature of human sex (social construct of sex), which in contrast to biological sex is formed on the basis of gender consciousness, in the process of gender roles and under the influence of social relations and cultural factors at macro-, meso- and micro-level" [3, p. 26]. According to T. Alekseenko, "such a definition of gender forms understanding that the difference in behavior, characters, relationships and social roles of the sexes are not innate characteristics and states, but constructed by society. It declares the socio-role status, which determines the social capabilities of a person - man and woman in all spheres of life" [3, p. 26].

Regarding the content analysis of the concept meaning of "gender", it should be noted that its derivative ("gender") cannot be used to replace another concept "sex". After all, here we see primarily social rather than biologically determined differences (wages for men and women for the same amount of work performed, stereotypes about getting leadership positions, women's priority in raising children and performing their functions as housewives, insufficient consideration of women's views on important (for example, political) decisions, stereotypes about their mastery of "male" professions, for example, in engineering and technical fields, etc. This article emphasizes the need to ensure equal rights and opportunities for women and men in their professional realization, gaining social status in various spheres of life and the absence of any restrictions or privileges on the grounds of sex in the training of future engineering professionals.

E. McCobby and K. Jacqueline, studying the influence of gender on behavior, identified three groups of gender differences: the first group - reliable (greater aggression of men, their advantages in mathematical and spatial operations, higher linguistic abilities of women); the second group - doubtful (men and women differ in obedience and caring, dominance, stress and anxiety, general level of activity, competition (competitiveness), tactile sensuality); the third group - combines the differences that have not been confirmed (for women - the decisive role of the environment for their development; large - suggestion and sociality, better success in solving problems that require standard solutions; smaller - self-esteem and the need for success, mainly the development of auditory analyzer .For men the determining influence of heredity on their development, the best success in performing complex and non-standard tasks, analytical cognitive style, etc.) [10].

It is no coincidence that the term "gender pedagogy" has appeared in the modern scientific literature, which is interpreted as an interdisciplinary component of pedagogical science that studies 
pedagogical phenomena and facts in relation to sexual characteristics of individuals formation and development of education.

Gender pedagogy is a set of approaches aimed at creating comfortable conditions in educational establishments for children socialization, an important component of which is the self-identification of the child as a boy or a girl [6]. Of course, this applies to educational institutions of various types, including universities, where students acquire relevant occupation.

The theory of gender education and upbringing distinguishes the following areas:

- study of pedagogical aspects of the process of gender socialization of girls and boys as subjects of school education, determining the influence of parents, peers, teachers, educational literature, network environment on the formation of gender identity of individuals of both sexes;

- identification of patterns of pedagogical influence of teachers on the gender identity of students creating an appropriate environment for self-realization of individual abilities of students [6].

Psychological and pedagogical research (T. Govorun, O. Kikinezhdi) shows that the tendency to change traditional gender roles appeared with the beginning of the development of industrial society, which accompanied the liberation of women from patriarchal influence due to their inclusion in social production. The dynamics of the social status of women, due to the achievement of economic independence, increasing their professional, cultural and educational levels, gave rise to the need to change the socio-psychological foundations of society, the development of partnerships with men. These socio-economic changes led to the emergence and spread of a new type of family in partnership, egalitarian (from the French egalite - equality) marital relations, sometimes called velvet [7, p. 220].

In the context of the gender approach, we consider a person not to be an abstract neutral integrity, but as a woman or a man in their equality, self-expression and self-affirmation, which is the most important social guideline in all spheres of democratic society [17, p. 192]. Gender upbringing of the individual is influenced by family, education, media, religion, art, language, legal and public policy. The introduction of a gender approach in the formation of a harmoniously developed personality offers a new reality, where there is no inequality and hierarchy of "male" and "female" [8].

Modern researchers (L. Vovk, N. Gapon, T. Govorun, O. Kikinezhdi, V. Kravets, etc.) rightly single out the concept of "gender culture", which is one of the basic components of personality culture in general, in training is a system of social -psychological conditions of existence of society, which contributes to the formation of man and woman as equal social beings.

Gender culture is "a system of ideas, values, knowledge, norms, interests and needs that shape the socio-cultural aspects of gender, establish the appropriate status of women and men, determine their roles, relationships and patterns of behavior in various spheres of life, influence the forms and results of creative activities of genders, determine their place in the picture of the world. Gender culture performs worldview, axiological, normative-regulatory, adaptive, humanistic, communicative, educational, etc. functions" [15].

Gender culture includes a number of components: gender (social and individual) consciousness, gender worldview, gender perceptions, gender knowledge, gender expectations, gender values, gender stereotypes, gender roles, gender relations, gender sensitivity, gender behaviors, gender needs, interests and results of creative activity, gender competence of a person, etc. [15].

S. Vyhor defines the structure of gender culture, which contains the following components: cognitive - aimed at forming sexual identity of the individual on the basis of perceptions of himself/herself as a representative of a particular sex, the content of gender roles and modern gender stereotypes, female and male personalities; emotional and value - recognition of the priority of universal values and equal rights for persons of different sexes, focus on partnerships and egalitarian marriage; behavioral - determines the implementation of mastered models of gender roles in their own lives by training appropriate actions in non-gender activities, training in respect for the opposite sex and adequate intersex communication [19, p. 110].

In the context of our study, it is necessary to define the content of gender competence as a result of gender education - a person's ability to realize situations of gender inequality in public life; to resist sexist, discriminatory actions and influences; show tolerance in situations of gender inequality. 
Related to our study is the concept of "gender socialization" as "the process of assimilation by an individual of the cultural system of gender of the society in which he/she lives. Gender socialization includes two interrelated components: an individual's assimilation of acceptable patterns of male and female behavior, attitudes, norms, values, and gender stereotypes.

The influence of society, social environment on the individual in order to instill in him/her certain rules and standards of behavior that are socially acceptable for women and men in this socio-cultural space" [15]. The characteristics of gender socialization as one of the areas of socio-pedagogical activity is studied by O. Budnyk, who emphasizes the overcoming of gender prejudices in the interaction of participants in the educational process. An important aspect of professional and pedagogical work is the propaedeutics of social isolation of the individual, which today is an acute problem in the educational institution, in the family, student environment, etc. [4, p. 75].

In psychological and pedagogical science there are two phases of gender socialization: adaptive external adaptation to existing gender relations, norms and roles; interiorization - essential assimilation of male and female roles, values, stereotypes [15].

\section{THE RESULTS OF EMPIRICAL RESEARCH}

To study certain gender aspects in the training of specialists in engineering and technical education institutions, we conducted a survey among students of Ivano-Frankivsk National Technical University of Oil and Gas. 110 future specialists of the following specialties took part in the survey: "Information Systems and Technologies", "Computer Engineering", "Software Engineering", "Oil and Gas Engineering and Technologies", "Environmental Technologies", "Tourism", "Architecture and urban planning", "Construction and civil engineering", "Electric power, electrical engineering and electromechanics", etc. The following specialties are in particular demand in the labor market today, so the important task of our study was to identify interest among men and women, as well as to analyze their motivation to choose a particular profession, gender and the presence / absence of gender discrimination. At the same time, we tried to balance respondents by gender. Therefore, the study involved: $46.4 \%$ - women and $53.6 \%$ - men.

An important question in our survey was to determine the impact of gender on the quality of vocational training. It turned out that $54.1 \%$ of respondents said that they do not consider gender to be a prerogative in choosing engineering professions, which testifies to the gender balance of these young people. At the same time, $18.3 \%$ of respondents are still inclined to the traditional men's priority in choosing and succeeding in computer or petroleum engineering. And there are some explanations for this, because for a long time in the post-Soviet countries, these professions were "male". At the same time, almost a third of young people feel a partial gender impact in vocational training. It is important that modern students are sufficiently emancipated and independent, they are mostly not subject to the traditional influences of society, but some "fears" or "complexes" about the ability to master the relevant competencies at a high level still exist.
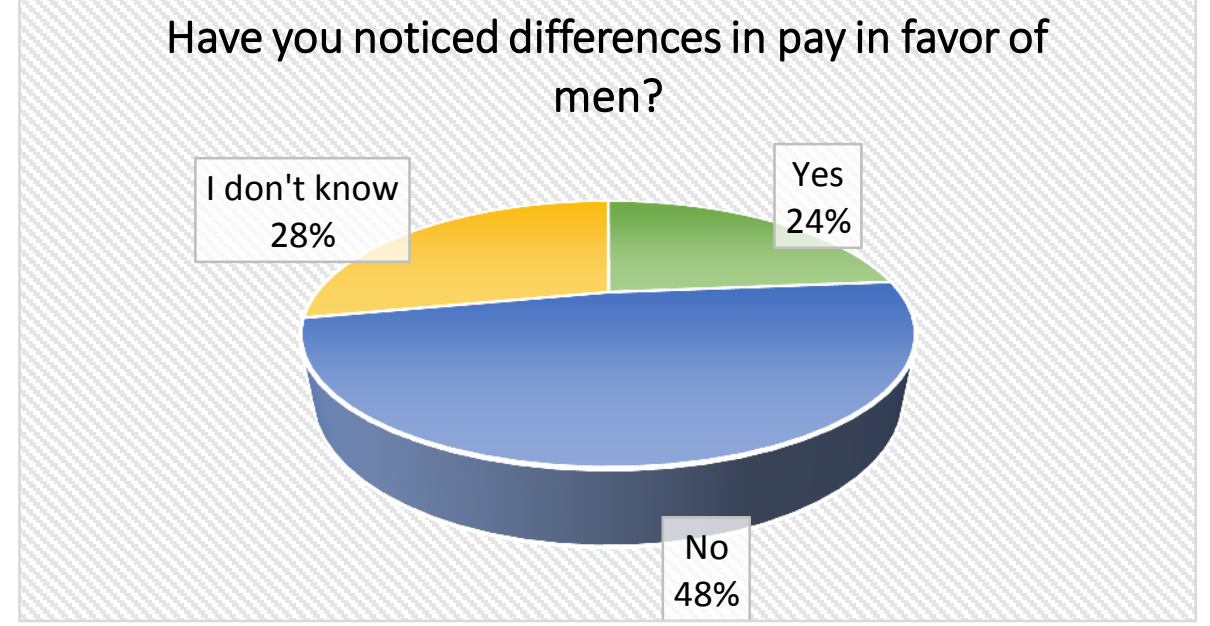

Fig. 1. Cases of gender differences in wages in favor of men. 
As a consequence of such discrimination, which, unfortunately, takes place in the modern world, we also have different salaries on the basis of gender (Fig. 1). After all, according to respondents, more than a third of them have encountered or witnessed such cases.

In Ukraine, the struggle for gender equality is advancing, but women still earn a quarter less than men. Such data were announced by the Ministry of Social Policy. Ukraine is currently preparing to join the International Coalition for Equal Pay [20]. At the same time, men and women play certain gender roles in their professional activities.

Gender roles are normative, they express certain social expectations and are manifested in behavior. They are always connected with some normative system, which the individual breaks in his/her consciousness and behavior. Some of these norms are perceived through the media and popular literature, a number of others we receive directly, for example, in the form of traditions, customs, parental guidance, or disapproving from society when we assume deviations from expected gender behavior [11].

Gender stereotypes in choosing a profession can in some way be seen as social norms. After all, the dominant notion is that men and women have certain sets of specific qualities and patterns of behavior, that the vast majority of people support this view and that they are usually aware of which behavior or area of professional activity is considered "correct" for each sex. These stereotypes are often passed down from generation to generation in the process of gender socialization. We tend to think that gender stereotypes in the professional sphere are mostly negative. In many countries, perceptions of the role of women contradict the active lifestyle, so many women are not inclined to self-realization in areas beyond the traditional. This applies primarily to "male" professions, which are obtained at a technical university.

According to research on gender stereotypes, for example, in the choice of police profession, "none of the male police officers approves of the quantitative parity in the police of women and men, $19 \%$ are inclined to believe that this is acceptable in principle, and $23 \%$ categorically oppose. Women express different point of view: $52 \%$ of surveyed women police officers believe that equal sex representation in the police is necessary or at least possible" [11, p. 31].The results of the study show that there are many more men than women in the captivity of the most common stereotype "policeman is an exclusively male profession". Thus, among male police officers, this view is shared in full or almost entirely by significantly more respondents than among their female colleagues ( $91 \%$ and $6 \%$, respectively), and, conversely, $94 \%$ of women and only $9 \%$ of men disagree with this statement [11, p. 30].

\section{Do you want gender equality in your profession?}

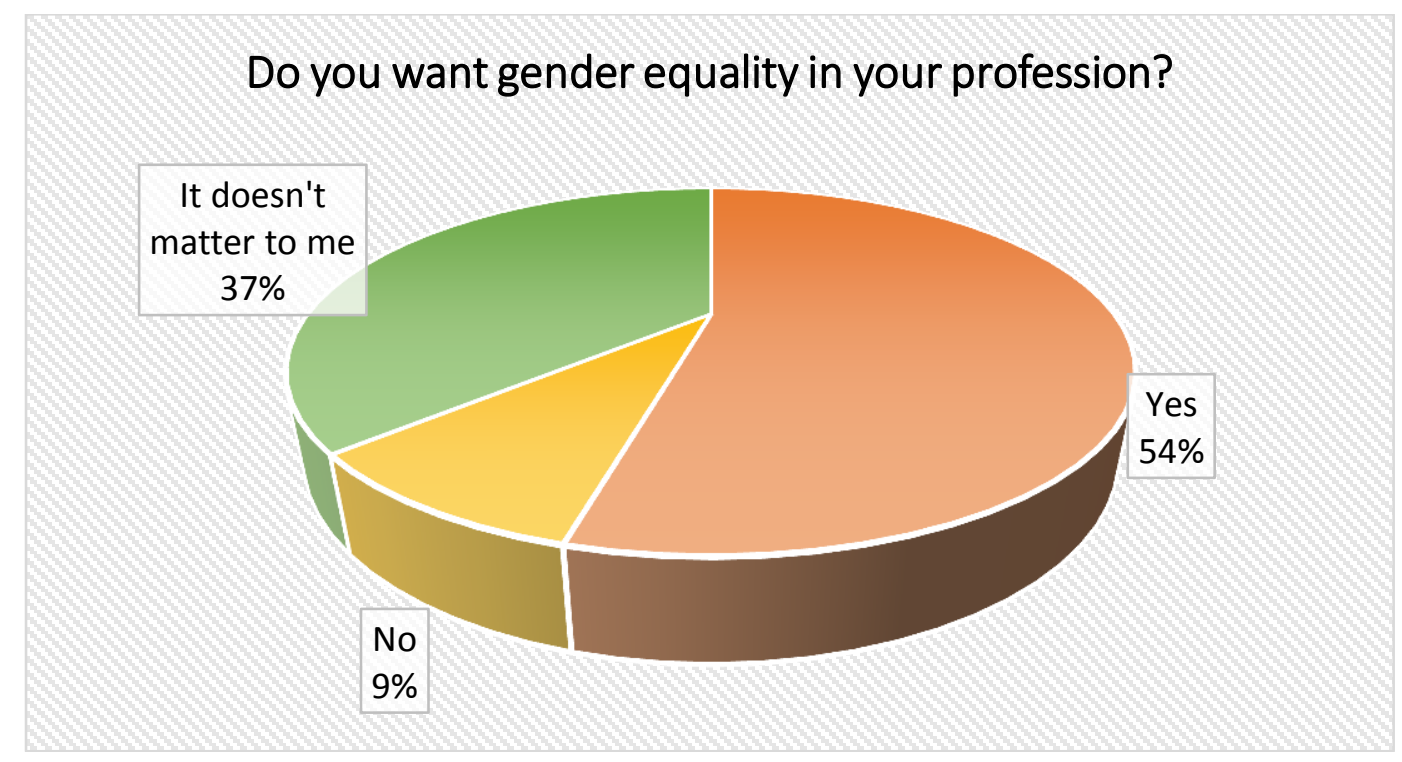

Fig. 2. Opinions of technical university students on gender equality in occupational choice. 
"Reducing gender inequality has many positive consequences for communities and societies. For example, according to the European Institute for Gender Equality (EIGR), the level of employment in the EU will make a significant leap if women have more equal opportunities in education, STEM (technology, engineering, mathematics) and in the labor market. This would lead to an increase in the level of female employment by $0.5-0.8 \%$ by 2030 and by $2.1-3.5$ by 2050 . Overall, the employment rate in the EU would reach almost $80 \%$. Gender equality has also been found to have a significant impact on Gross Domestic Product. Projected strengthening gender equality could increase GDP per capita within $6,1-9,6 \%$ by 2015 and $2 \%$ in 2030 due to the increase of female employment in the productive sectors. Improving gender equality in education, employment and a more balanced distribution of reproductive labor between women and men is also expected to increase birth rates. The EIGR estimates that increasing gender equality could increase the birth rate to $8 \%$ by 2030 ." [16].

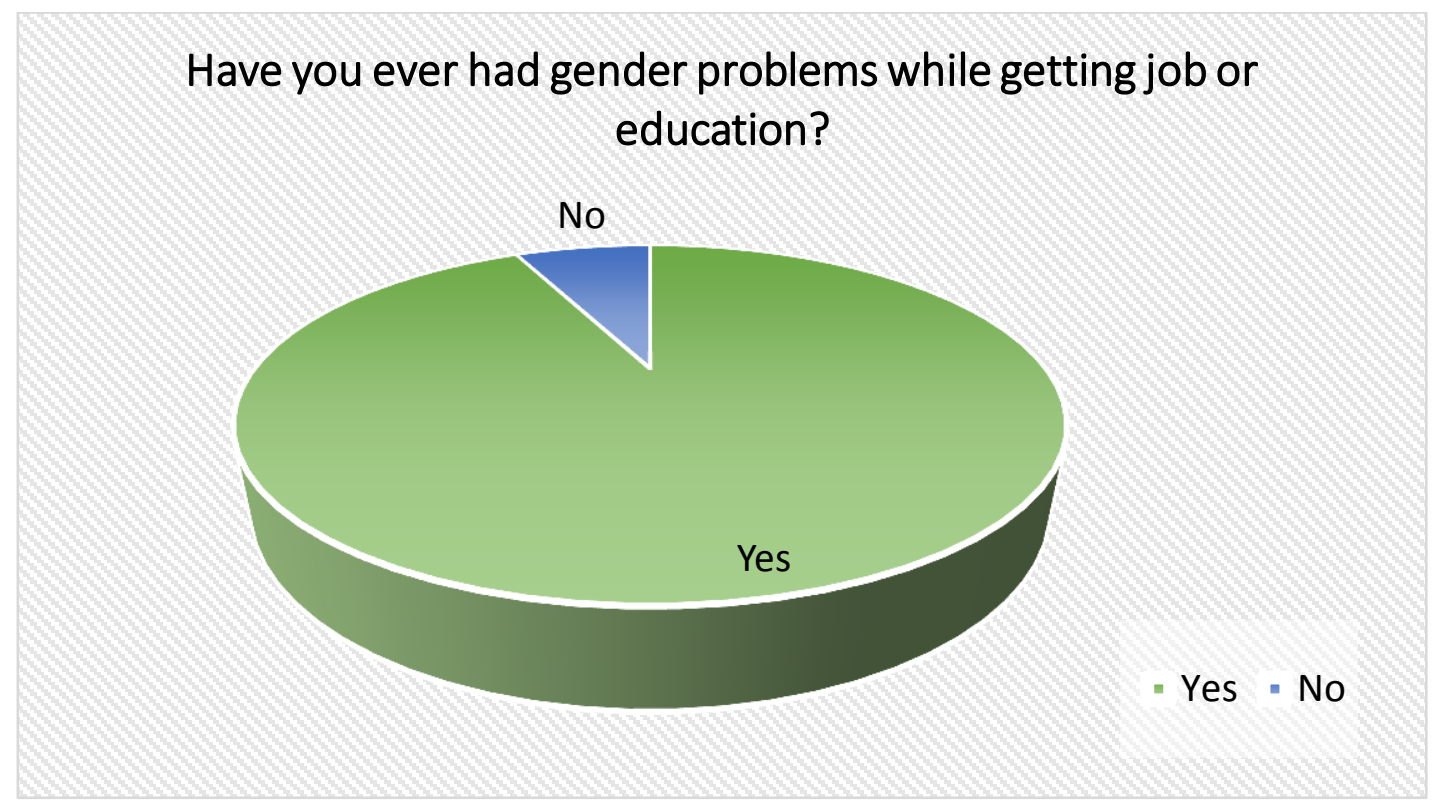

Fig. 3. The influence of gender stereotypes on technical university students' choice of labor (education) economic and other areas of professional activity.

Therefore, it is no coincidence that our next question is "Have you ever felt gender discrimination in professional work in your life?" we addressed technical educationstudents. Taking into consideration the fact that most of them are still studying and have no practical experience in such activities, $40.4 \%$ of respondents said they "cannot remember" such situations and a third (31.2\%) - have not encountered that phenomena. However, it is upsetting for future professionals in this field, $28.4 \%$ of respondents answered that gender discrimination took place in their lives. As it turned out, these are mostly female, as there are still social stereotypes about their competence in engineering. Thus, the problems of gender discrimination have a negative impact on the economic development of the country and the nation. Stereotypical thinking about the position of men and women in the economic system and public life plays an important role in maintaining gender inequality. At the same time, "negative gender stereotypes are more subjective than objective, which allows us to hope for a fundamental possibility of overcoming them in law enforcement agencies and society as a whole" [11, p. 33].

\section{CONCLUSIONS}

Thus, gender approach is a kind of theoretical theory, concept, on the basis of which a new direction in science is developing - gender research, which is of interdisciplinary nature. At the same time, gender studies are of great interest for pedagogy and psychology, because they relate to the gender-role socialization of a person, his/her personal and professional development. 
The formation of gender competence of university students is a complex and purposeful pedagogical activity, as a result of which a person has the opportunity to express his/her competence in situations with an obvious gender component. Regarding engineering specialists training, the emphasis should be on overcoming gender stereotypes and ideas about the performance of certain professional (social) roles by representatives of male or female gender.

It was found that the gender factor and dominant stereotypes partially affect the professional selfdetermination of future professionals in this field.

The study revealed that gender stereotypes about the career choice still exist in society: $38 \%$ of the total number of respondents indicated stereotypes in society about the "masculinity" of engineering professions.

Prospects for further research -improving vocational guidance of high school students to promote engineering professions profile and avoid gender stereotypes about their choice.

\section{REFERENCES}

[1] Association Agreement between the European Union and its Member States, of the one part, and Ukraine, of the other part. Available at: https://knute.edu.ua/file/NjY4NQ==/9ece50fd0ddffd98b924630447a49336.pdf. (in Ukrainian)

[2] Alieksieieva A.V. Psychological gender as a factor in the formation of personal identity in adolescence: dis.of Cand. Psychol. Science: 19.00.07. Institute of Psychology named after G.S. Kostyuk, Academy of Pedagogical Sciences of Ukraine, 2006. Available at: http://www.disslib.org/psykholohichna-stat-jakchynnyk-stanovlennja-osobystisnoyi-identychnosti-u-junatskomu.html. (in Ukrainian)

[3] Aljeksjejenko T.F. Gender concept of family upbringing as a scientific and socio-pedagogical problem. Available at: http://lib.iitta.gov.ua/107219/1/\%D0\%90\%D0\%BB\%D1\%94\%D0\%BA\%D1\%81\%D1\%94\% D1\%94\%D0\%BD\%D0\%BA\%D0\%BE\%20\%D0\%A2.\%D0\%A4.pdf. (in Ukrainian)

[4] Budnyk O.B. Socio-pedagogical activity of a primary school teacher: a manual. PP Boichuk A.B., IvanoFrankivsk, 2012. (in Ukrainian)

[5] Budnyk O. Theoretical principles of using STEAM-technologies in the preparation of the teacher of the New Ukrainian school. Journal of Vasyl Stefanyk Precarpathian National University, 5 (1) (2018), 23-30. doi: 10.15330/jpnu.5.1.23-30.

[6] Gender education as an urgent need of the modern educational system. http://osvita.ua/school/method/upbring/330/

[7] Hovorun T.V., Kikinezhdi O.M. Gender and sexuality: a psychological perspective: a guide. Navchalna knyha - Bohdan, Ternopil, 1999.(in Ukrainian)

[8] Khoriakov V.A. Pedagogical conditions of gender education of students in higher pedagogical educational institutions: dis. of Cand. ped. Science: 13.00.07 "Theory and methods of education". Luhansk, 2010. (inUkrainian)

[9] Kokarieva A. Features of professional training of future specialists in the system of engineering education of Ukraine. Bulletin of the National Aviation University. Series: Pedagogy, Psychology, 12 (2018). Available at: http://jrnl.nau.edu.ua/index.php/VisnikPP/article/view/13218. doi: 10.18372/2411264X.12.13218.

[10] Kravets V.P. Gender pedagogy: a textbook. Dzhura, Ternopil, 2003.(in Ukrainian)

[11] Lapshyna V. Gender stereotypes in the professional sphere: origins, status and prospects of existence. Sociology, 4 (9) (2005), 27-34. (in Ukrainian)

[12] Lutsenko O.A. Gender education and pedagogy. In: Fundamentals of Gender Theory: a handbook. “K. I. S.", Kiev, 2004. (in Ukrainian)

[13] Nurjanah N.,Suryadi A., Abdulhaq I., Hatimah I., Budimansyah D. Gender-Sensitive Effect of ProblemBased Learning on Student Performance in Indonesian Teacher College Classes. The New Educational Review, 55 (2019), 54-63. doi: 10.15804/tner.2019.55.1.04. 
[14] Palahniuk M. Gender aspects of training specialists in engineering and technical education institutions of Ukraine. Educational Horizons, 2 (2020), 27-32. (in Ukrainian)

[15] Shevchenko Z.V. (Ed.) Dictionary of gender terms. Available at: http://a-z-gender.net/ua /\%D2\%91ender.html. (in Ukrainian)

[16] Tsokur O. Fundamentals of gender education. Gender development in society. HRC "Foliant", Kyiv, 2005. (in Ukrainian)

[17] Why dogender science sconstantly manipulate statistics? Available at: https://povaha.org.ua/chomuhenderni-nauky-postijno-manipulyuyut-statystykoyu/. (in Ukrainian)

[18] Vasylenko O.M. Features of the choice of future profession by entrants of higher educational institutions: gender aspect. Scientific Bulletin of Uzhhorod National University: Series: Pedagogy. Social work, 32 (2014), 32-34.(in Ukrainian)

[19] Vykhor S.T. Gender education of senior adolescents and early adolescents: dis. ... Cand. ped. Science: 13.00.07. Thernopil, 2006. (in Ukrainian)

[20] Women in Ukraine earn a quarter less than men. Available at: https://economics.segodnya.ua/ua/economics/business/zhenshchiny-v-ukraine-zarabatyvayut-nachetvert-menshe-muzhchin-1279440.html. (in Ukrainian)

Address: Palahniuk Mykhailo, Ivano-Frankivsk National Technical University of Oil and Gas, 15 Karpatska St., Ivano-Frankivsk 76000, Ukraine.

E-mail: palagnuk3001@gmail.com.

Received: 26.01.2021; revised: 09.03.2021.

Палагнюк Михайло. Підготовка фахівців інженерно-технічного профілю: гендерні стереотипи у професійній сфері. Журнал Прикарпатського університету імені Василя Стефаника, 8 (1) (2021), 72-79.

У статті висвітлено актуальність проблеми підготовки фахівців інженерно-технічного профілю 3 урахуванням розвитку технологій та суспільних викдиків ринкової економіки. Наголошено на потребі забезпечення гендерної рівності у виборі професій інженерно-технічного профілю, рівних мождивостей для чоловіків та жінок. Обгрунтовано сутність понять: "гендер", "гендерна педагогіка", “гендерна культура", “гендерна соціалізація", “гендерні стереотипи", “гендерна компетентність", "гендерне виховання", “гендерна нерівність", "гендерні ролі" та ін. Визначено, що дослідження гендеру становлять вагомий інтерес для педагогічної і психологічної науки, оскільки стосуються статевородьової соціалізації людини, іiі особистісного і професійного розвитку. Представлено результати емпіричного дослідження з вивчення гендерних стереотипів у виборі професійного фаху серед студентів Івано-Франківського національного технічного університету нафти і газу (в опитуванні взяли участь 110 осіб). З'ясовано, що гендерні ознаки у значної частини мододих дюдей не $є$ прерогативою вибору професій інженерно-технічного профілю, однак все ще існують такі стереотипи у суспільстві. Виявлено, що для майбутніх фахівців цієї галузі гендерна дискримінація мала місце в їхньому житті (28,4\% респондентів) і це здебільшого дівчата, котрі здобувають технічні професії. Третина студентів (32\%) зізналися, що стикалися з випадками несправеддивої оплати праці за гендерною ознакою на користь чоловіків. Доведено, що негативні гендерні стереотипи носять більшою мірою суб'єктивний, ніж об'єктивний характер, що дозволяє сподіватися на принципову мождивість їх подолання в професійній підготовці фахівців в технічному університеті.

Кдючові слова: гендерна педагогіка, гендерна культура, гендерні стереотипи, професійна підготовка, інженерно-технічна освіта, гендерна рівність, гендерна дискримінація. 